\title{
DIE VERWERKLIKING VAN DIE GELOOF IN DIE KERKLIKE KATEGESE: BASISTEORETIESE PERSPEKTIEWE
}

\author{
C.J.H. Venter ${ }^{1} \&$ C.N. van der Merwe $^{2}$
}

\author{
ABSTRACT \\ THE REALISATION OF FAITH IN \\ ECCLESIASTICAL CATECHESIS: \\ BASIS-THEORETICAL PERSPECTIVES
}

\begin{abstract}
Relevant subject-related literature and empirical studies indicate that the relation of children of the covenant with God often stagnates after their confirmation of faith. Furthermore, they often do not progress towards experiencing their faith. According to empirical data and views expressed in subject-related literature, it seems as if the Bible and biblical material are treated only objectively during the years of catechetical instruction and children are often not guided adequately towards a subjective experience of their faith. Dogmatically this article highlights the relation between the objective receiving of salvation (fides quae creditur) and the subjective receiving and practising of salvation (fides qua creditur). The grace of God does not imply that children of the covenant become passive beings. On the contrary, the promises and the call of salvation require of children of the covenant to acquire an active attitude towards faith and to experience the total extent of the covenant of grace. In the course of catechetical instruction children of the covenant should be actively guided to share in God's covenantal grace. The baptism of children of the covenant actually implies an urge and responsibility towards a new obedience. God also uses the means of ecclesiastical catechism to guide children through the activity of the Word and Spirit towards the receiving of salvation. The promises of God, however, require a response. The confirmation of faith should lead to the experiencing and realisation of faith.
\end{abstract}

1 Prof. C.J.H. Venter, Departement Praktiese Teologie, Skool vir Kerkwetenskappe. Noordwes-Universiteit, Potchefstroomkampus, Potchefstroom, 2520. E-pos: kwscjhv@puknet.puk.ac.za

2 Dr. C.N van der Merwe, Departement Praktiese Teologie, Skool vir Kerkwetenskappe. Noordwes-Universiteit, Potchefstroomkampus, Potchefstroom, 2520. E-pos: nicovandermerwe@cinet.co.za 


\section{OPSOMMING}

Tersaaklike vakliteratuur en empiriese ondersoeke toon dat verbondskinders se verhouding met God dikwels stagneer nadat hulle belydenis van geloof afgelê het. Ook skyn dit asof hierdie kinders dikwels nie ontwikkel tot die belewing van hulle geloof nie. Volgens empiriese data en menings wat uitgespreek word in tersaaklike vakliteratuur kom dit voor asof die onderrig in kerklike kategese hoofsaaklik objektief met die Bybel omgaan en dat verbondskinders nie genoegsaam begelei word tot 'n subjektiewe belewing van hulle geloof nie. Dogmaties benadruk hierdie artikel die verhouding tussen die objektiewe ontvang van die heil (fides quae creditur) en die subjektiewe toe-eiening en uitlewing van die heil (fides qua creditur). Die genade van God impliseer nie dat verbondskinders passiewe mense word nie. Inteendeel, die verbondsbeloftes en -eise vra 'n aktiewe benadering van geloof en die ondervind van die volle reikwydte van God se genadeverbond. In die proses van kategetiese onderrigleer moet verbondskinders op 'n aktiewe wyse begelei word om God se genade deelagtig te word. Verbondskinders word immers deur die doop vermaan en verplig tot 'n nuwe gehoorsaamheid. God gebruik ook die kerklike kategese as middel om verbondskinders deur die werking van Gees en Woord tot heilstoe-eiening te lei. Die "beloof” van God roep om "geloof". Belydenis moet uitloop op belewenis en verwerkliking.

\section{PROBLEEMSTELLING}

Reeds Calvyn skryf in die derde boek van sy Institusie (Simpson 1984: 3.699) oor die manier waarop ons die genade van Christus ontvang, oor die voordele wat dit vir ons inhou en oor die resultaat daarvan in ons lewe. Christus deel sy weldade uit, die mens ontvang dit en moet daarmee werk (vgl. Velema 1987a:126). Vanweë die sonde verkeer die mens in 'n toestand wat verander moet word deur dit wat God gee. In hierdie proses kom nie net die inhoud van die weldade ter sprake nie, maar ook die wyse waarop dit deel word van die gelowige en hoe die weldade in die geloof verwerklik word in sy of haar lewe. Hierdie uitdeel, ontvang en verwerklik van die geloof vind ook langs die weg van kerklike kategese plaas.

Tans ontvang veral die dimensie van die verwerkliking van die geloof langs die weg van kategetiese onderrig weer opnuut aandag in toepaslike wetenskaplike besinning. Sedert die verskyning van die werk Creative Bible teaching van Richards in 1970 en die hersiening en uitbreiding daarvan deur Richards en Bredfeldt in 1998 het die saak van die verbondskind se geloofsverwerkliking in die praktyk van die lewe langs die weg van die kategetiese begeleiding opnuut na vore gekom. Bybelse 
waarhede moet nie onderrig word as abstrakte waarhede wat bo die lewenswerklikheid sweef nie, maar as "truth into life" (Richards \& Bredfeldt 1998:113). Die laaste stelling word ook bevestig deur Wilson (2000:597) as hy skryf: "Teaching has not been effective until obedience has begun." Hierdie beklemtonings het nie net betekenis vir godsdiens in die algemeen nie maar ook vir kategese in besonder. Genoemde stellings lê klem daarop dat wat in die kategese aan verbondskinders bedien word, in hulle konkrete lewe sigbaar moet word in dade van geloof.

Dit is egter nie net in toepaslike literatuur dat die vraagstelling van die verwerkliking van die geloof in die kerklike kategese na vore kom nie. Ook empiriese ondersoeke in Suid-Afrika bring bepaalde tendense wat met die probleemstelling verband hou, na vore. Die outeurs van hierdie artikel het uiteraard die fokus van hulle navorsing skerp gerig op die situasie in die Gereformeerde Kerke in Suid-Afrika, in besonder op besluite van Nasionale Sinodes (vgl. GKSA 1961, 1988, 1991). In hierdie besluite funksioneer bepaalde empiriese gegewens. Hierby is ook betrek die empiriese resultate van 'n ondersoek van die Nederduitse Gereformeerde Kerk (vgl. Prins 2000), onder andere oor die konkretisering van die geloof in die lewe van tieners. Die volgende sake van belang vir hierdie artikel het in bogenoemde ondersoeke na vore gekom:

- By die skoolgaande en naskoolse jeug is 'n groot gebrek aan die aktualisering van hulle geloof. In die kategese word Christus se soenverdienste as die enigste grond van ons ewige saligheid aan verbondskinders bedien. Die konsekwensies van die heilsfeite word vir die jongmense benadruk en ook die feit dat die katkisante dit nie alleen net moet bely nie, maar ook moet belewe en uitlewe (vgl. GKSA 1961:346).

- 'n Groot persentasie van die laer- en hoërskooljeug ruim nie op 'n gereelde basis tyd vir persoonlike Bybellees in nie. Hulle het dus nie 'n vaste roetine vir Bybellees nie en ook nie 'n goeie Bybelleesmetodiek nie. Derhalwe verval die Bybellees van tieners in 'n rond-en-bontleespatroon (vgl. GKSA 1988:803).

- Erediensbywoning van die skoolgaande jeug, veral wat die aanddienste betref, is nie na wense nie. Alhoewel die meerderheid die verantwoordelikheid ten opsigte van erediensbywoning besef, ontbreek die begeerte en die verantwoordelikheid dikwels. 'n Groot persen- 
tasie van veral die laerskooljeug woon die oggenderedienste net by omdat die katkisasie na die diens plaasvind. Die skoolgaande jeug onthou die prediking ook nie goed nie en het probleme as dit by die uitvoering van die prediking kom (vgl. GKSA 1988:807 en ook Prins 2000).

- Die erediensbywoning van die naskoolse jeug is bevredigend, maar net $50 \%$ skakel aktief by die gemeentelike lewe in. Jong belydende lidmate raak dikwels die binding met die kerk kwyt kort na belydenisaflegging en toon geen belangstelling vir kerklike aktiwiteite nie en hulle word baie moeilik tot meelewendheid met die kerk beweeg. ${ }^{3}$ Dit lyk asof hulle vasgesteek het by die geloofsbelydenis en nie oorgegaan het tot geloofsbelewenis en geloofsdade nie. Aflegging van belydenis van die geloof het in die Gereformeerde Kerke in SuidAfrika dalk meermale al die eienskap van 'n outomatiese handeling gekry in dié sin dat verbondskinders "outomaties" in Graad 11 of 12 belydenis doen.

- Die naskoolse jeug staan soms onverskillig en opstandig teenoor geykte gebruike, konvensies, belydenisskrifte, Bybel en kerk. Dit kom voor asof hulle al die jare net objektief met die Bybel omgegaan het en dat daar nie by hulle subjektiewe belewing was nie (vgl. GKSA 1991).

Die resultate wat verkry is op grond van vraelyste laat egter ook opvolgvrae ontstaan: Was die kategese en die uiteindelike belydenisondersoek nie dalk te intellektualisties as gevolg van die skeiding tussen die objektiewe kennis en die subjektiewe vertroue nie? Het hierdie skeiding nie 'n invloed uitgeoefen op die verwerkliking van die geloof in dade nie?

'n Aspek wat by die aard en proses van kategese ook nie buite rekening gelaat moet word nie, is die volgende: Die kognitiewe dimensie in kategetiese onderrig is van groot belang. Die kognitiewe moet egter ook aangevul word met inagneming van die affektiewe, normatiewe, konatiewe en religieuse potensiaal van die verbondskind met die oog op die realisering van die geloof langs die weg van kerklike kategese.

3 Die bewering dat jongmense eers weer na hulle huwelik aan die gemeentelike lewe begin deelneem, word deur $70 \%$ van die kerkrade van Gereformeerde Kerke in Suid-Afrika gestaaf. 
Hierby moet in die kategese ook indringend aandag gewy word aan die religieuse en aktuele werklikhede waarbinne die kind lewe.

\section{OBJEKTIEWE GELOOFSINHOUD EN SUBJEKTIEWE GELOOFSDADE}

Dogmaties word die objektiewe ontvang van die heil die fides quae creditur genoem en die subjektiewe toe-eiening van die heil deur die geloof word die fides qua creditur genoem. ${ }^{4}$

- Quae dui op die objektiewe geloofsinhoud: "Faith is the content of my confession, the contents of faith" (Deist 1984:95). In die quae wys die nominatief op wat geglo word - die inhoud van die geloof "wordt bepaal door Gods openbaring" (Velema 1990:84).

- Qua wys op die subjektiewe geloofsdade. "The act of faith leading to faith, i.e. the ground or foundation of faith, namely the work of the Holy Spirit" (Deist 1984:95). In qua wys die ablatief op die waardeur geglo word. Velema (1990:84) beklemtoon dat die inhoud van die geloof "evenzeer bepaald wordt door Gods openbaring".

Die vraag moet nou beantwoord word: Gaan dit in die kategese om die quae, die objektiewe geloofsinhoud (die heilshistoriese) of gaan dit om die qua, die subjektiewe geloofsdade (die heilsordelike) of gaan dit om albei? Dit is die sentrale probleemstelling in hierdie artikel.

\section{SUBJEKTIEWE EN OBJEKTIEWE ASPEKTE VAN HEILSTOE-EIENING}

Vir die verloop van hierdie ondersoek is dit nodig om sekere verbandhoudende begrippe te onderskei.

Die leeruitkoms van die kategese is daarop gerig om verbondskinders te lei tot heilsekerheid en heilstoe-eiening en nie net tot geloofsekerheid en geloofsbelydenis nie. Geloofsekerbeid (certitudo fidei) het betrekking op die objektiewe waarbeid van die godsdiens en vra nie direk na die praktiese toepassing daarvan nie. Heilsekerbeid (certitudo salutis) het betrek-

$4 \mathrm{Na}$ die fides qua creditur en die fides quae creditur word daar in die res van die artikel nét verwys as qua en quae. Met qua word dus bedoel fides qua creditur en met quae word bedoel fides quae creditur. 
king op die subjektiewe deel in die heil van die Here en vra na die praktiese toepassing daarvan.

Geloofsekerheid (certitudo fidei) word só deur Heyns (1978:310) beskryf:

Geloofsekerheid is die seker-wees van Hom in Wie geglo word; dis die sekerheid van die uitverkiesing en roeping (Rom. 8:30); die sekerheid van die profetiese woord wat vas is (2 Pet. 1:19); die sekerheid van ons kindskap van God (Rom. 8:16); die sekerheid van die bloed van Christus wat ons die heiligdom laat binnegaan (Hebr. 10:19); die sekerheid van harte wat deur besprinkeling gereinig is (Hebr. 10:22); die sekerheid van 'n oorgang uit die dood in die lewe (1 Joh. 3:14); ja, die sekerheid van die verseëling en die ontvangs van die Heilige Gees as onderpand in ons harte (2 Kor. 1:22).

Die heilsekerheid (certitudo salutis) is egter 'n aspek van die ryke skat van die regverdiging van die gelowige (Wentsel 1995:441). Dit is die sekerheid van deel hê aan Christus en aan alle heil wat Hy vir die mens verwerf het omdat jy deel het aan die heil en daaruit lewe. Om seker te wees van die heil het 'n tweeledige aard: (a) dit het betrekking op die objektiewe waarheid van die godsdiens en (b) dit het betrekking op die subjektiewe deel in die heil van die Here. Om hierdie onderskeiding, wat nie as 'n skeiding bedoel is nie, ook in die terminologie tot uitdrukking te bring, kan die oortuiging dat die mens persoonlik deel het aan die heil, heilsekerheid genoem word. Dit is 'n sekerheid wat slegs deur middel van die geloof te verkry is. Geloofsekerheid is op heilsekerheid gerig en heilsekerheid kan nie onafhanklik van geloofsekerheid bestaan nie. Die onderskeid tussen geloofsekerheid en heilsekerheid kan soos volg geformuleer word:

Heilsekerheid is sekerheid van die vergewing van sondes, die vernuwing van die lewe, die gemeenskap met God, die kindskap van God, die verkiesing, die volharding en die ewige lewe: "Het is de zekerheid van het deel hebben aan Christus en aan alle heil, dat Hij verwierf" (Van Genderen 1977:415). Jy kan nié die term geloofsekerheid gebruik as jy bedoel om sekerheid te hê dat jy 'n ware gelowige is nie, en dié sekerheid dan te wil onderskei van heilsekerheid nie. Heilsekerheid is immers die sekerheid aangaande die werklikheid en egtheid van die geloof.

Weliswaar is my geloof ' $n$ gawe van die Gees van God, maar dit beteken nog nie dat ek daarom op my geloof mag vertrou nie. Goeie werke is, as vrug van die Gees, tog ook gawes van God, maar daaruit volg nie dat ek op my goeie werke mag vertrou nie. Wie op sy 
goeie werke of op sy geloof vertrou, al is dit gawes van God, vertrou op homself (Theron 1985:303).

Heilstoe-eiening is die subjektiewe verwerkliking van die objektiewe heil wat God ons toesê. Toe-eiening is die proses waardeur die objektiewe heil in Christus subjektief deel gemaak word van die gelowige en realiseer in geloofsdade (geloofsverwerkliking). God vra van die verbondskind 'n blye en aktiewe instemming met en aanvaarding van die beloftes en die eise van die genadeverbond. Verbondskinders moet daartoe kom om dit wat objektief in die verbond belowe is, persoonlik deelagtig te word; dit is die daad van heilstoe-eiening. Die verbond is die verseëling van die belofte van God. Geloof en bekering as antwoord op die belofte is die heilstoe-eiening. In die ontvang van die heil gaan dit dus ook om goddelike heil en menslike outonomie. Geloof as 'n menslike moontlikheid moet daarom verstaan word in die lig van die verkryging van die heil wat deur God bewerk is (Jonker 1981:137). Die vraag is hoe die mens betrek word by die verlossing in Christus en hoe die kategese as middel kan dien om verbondskinders te lei tot heilsekerheid, heilstoe-eiening.

Oor hierdie saak is daar twee teenoorstaande standpunte:

- Enersyds word geleer dat 'n mens géén "aandeel” in sy redding het nie vanweë God se genade waarmee Hy die mens, sonder enige verdienste, red.

- Andersyds is daar die standpunt dat die mens eers bewustelik die genade van God moet "aanneem" anders kan hy nie gered word nie.

Eersgenoemde standpunt vind sy uitgangspunt in die verbond, terwyl laasgenoemde standpunt die aksent op persoonlike bekering lê (Strauss 1989:80). Op hierdie punt kom twee "teologieë" teenoor mekaar te staan:

- 'n "Ontspanne verbondsteologie" met 'n neiging tot objektivisme (die redding gebeur alles buite die mens sonder sy toedoen — hy ontvang maar net; die mens is in hierdie saak passief).

- 'n "Oorspanne bekeringsteologie" met 'n neiging tot subjektivisme (die redding kom eintlik eers binne in die mens tot stand as die heil 'n werklikheid word in die lewe van die mens - in hierdie proses is die mens aktief). 
'n Teoloog staan in hierdie opsig voor 'n dilemma: Wat moet hy doen? Moet hy 'n keuse maak tussen verbond en bekering? Daar moet vasgestel word wat die verhouding is tussen 'n ontspanne verbondsteologie en 'n oorspanne bekeringsteologie. Een van die vernaamste vrae waarmee die Pneumatologie deur die eeue geworstel het, is hoe die Heilige Gees betrokke is by die inbring van die heil in die menslike eksistensie (Jonker 1981:137).

\section{GELOOF IS OOK 'N DAAD}

Die Heidelbergse Kategismus, vraag 21, kan nie wat sy betekenis betref, geïsoleer word van vraag 22 nie. In vraag 21 val die klem op die individuele sy van die geloof. Die ons-karakter van die geloof kom in vraag 22 na vore. Calvyn se definisie van geloof moet hierby in gedagte gehou word:

Geloof is die vaste kennis van die welwillendheid van God gegrond in die waarheid van sy belofte in Christus en deur die Heilige Gees geopenbaar en besël (Institusie, 3.2.7:717).

By Calvyn is daar ' $n$ onderskeid tussen kennis en vertroue, maar hierdie onderskeiding moet nie gesoek word in quae (objektiewe geloofskennis) nie, maar wel in qua (subjektiewe geloofsdade) (Graafland 1961:27).

Ze kan het best zo geformuleerd worden, dat de kennis vooral de objectieve zekerheid van het heil aangeeft, zoals God dit in zijn Woord heeft geopenbaard, terwijl het vertrouwen vooral gericht is op de subjectieve zekerheid van het heil, dat is de zekere wetenschap van het persoonlijk deel hebben aan de genade Gods in Christus (Graafland 1961:28).

Geloofsekerheid bestaan uit kennis (scientia) van die betroubaarheid van God en sy genade. Die geloof rus nie op menslike gissings en vermoedens nie, maar op die objektiewe sekerheid, dit is die objektiewe geloofsinhoud wat die gelowige uit die Bybel kry.

Geloof is vanuit hierdie hoek 'n aktiwiteit van die mens. Met geloof doen die mens iets: sy doen $(q u a)$ word gerig deur die geloofsinhoud (quae). Daarby is geloof 'n persoonlike saak. Geloof impliseer aan die een kant objektiewe geloofskennis en aan die ander kant subjektiewe geloofsdade. Die objektiewe geloofsinhoud lê buite die mens in die 
Woord van God waaruit die mens dit verkry. Subjektiewe geloofsdade lê in die mens as 'n reaksie op die geloofsinhoud, die antwoord wat bestaan uit geloof en bekering.

Indien die twee aspekte van die geloof, naamlik vasstaande kennis (quae) en vaste vertroue (qua), van mekaar losgemaak word en die een ten koste van die ander oorbeklemtoon word, kan dit tot valse objektivisme of valse subjektivisme lei. Wie die qua nie deur die quae laat bepaal nie, dwaal. Wie hom tot die quae beperk en nie die qua in die oog hou nie, verval in rasionalisme wat moralisme as tweelingsuster het. Die qua mag nie individualisties verstaan word nie, maar wel individueel en eksistensieel. Daardeur word die balans bewaar:

When we deal with faith as a subjective attitude (the qua) we deal at the same time with the faith that is believed, the contents of faith (the quae) (Berkhof 1990:32).

Later in dieselfde werk skryf Berkhof (1990:444):

To avoid confusion, a distinction now commonly made is that between qua (the act of believing) and quae (the content of faith).

Ook vermaan Berkhof (1990:444) die leser:

This is a necessary but dangerous distinction; it threatens to tear apart as "subjective" and "objective" what in the covenantal fellowship belong together as the two sides of one event.

As subjektiewe daad is die geloof tegelyk besig met wat objektief geglo word én die persoonlike deelhê aan die heil omdat die objektiewe sekerheid van die geopenbaarde heil slegs die helfte van die waarheid is - vertroue as die ander helfte moet nog bykom. Iemand kan kennis hê sonder vertroue, maar vertroue is nie moontlik sonder kennis nie:

En omdat de objectieve zekerheid logisch aan de persoonlijke zekerheid voorafgaat, moet ook de kennis aan het vertrouwen voorafgaan. Het laaste word uit de eerste geboren (Graafland 1961:29).

\section{GELOOF IS 'N DAAD VAN AANVAARDING}

Geloof is ook 'n aksie van die mens. Geloof is 'n daad van aanvaarding. Geloof het volgens Velema (1990:84) inhoud én dit is 'n daad.

Faith is an action word. We cannot passively respond to God. We demonstrate what we believe by how we live our lives. If we believe 
it, we wil do it. If we don't, then what we believe is just wishful thinking (Anderson 1993:211).

Geloof kan nie bestaan sonder die daad van die geloof nie. Daar is geen geloof sonder die subjek wat glo en doen nie. Die geloofsverhouding met die Seun van God is 'n lewende verhouding.

Die vraag kom vanself na vore oor watter rol die mens toekom wanneer die Gees deur die Woord die geloof in die hart van die uitverkorenes werk. Die vraag is: Het die mens in hierdie werking 'n eie aktiewe rol? Die inhoud van God se Woord verhoed ons om van die geloof ooit te praat as 'n prestasie van die mens — 'n prestasie wat deur die mens gelewer moet word as voorwaarde vir die toegang tot die heil. Die feit dat Christus die heil verwerf en die Heilige Gees die heil skenk, beteken nie dat mensewerk in hierdie saak uitgeskakel word nie, maar dat die Heilige Gees "zich in zijn toepassend werk juist wil bedienen van mensen (Verboom 1989:66). Berkhof (1973a:274) gebruik in hierdie verband die woord "participatio", waarmee hy bedoel "dat God de mens als verbondspartner betrekt in het heilsgebeuren".

Geloof word nie buite die beslissing van die mens om gewerk nie, maar dit is juis die krag van die evangelie, waarin Christus as die gekruisigde afgeskilder word (Gal. 3:1) wat die mens tot geloofsbeslissing bring. Die Gees skep deur die Woord juis die moontlikheid dat die menslike subjek voluit kan funksioneer in vryheid en verantwoordelikheid. Anders sou die vele parakletiese gedeeltes (imperatiewe) in die Nuwe Testament onbegryplik wees. 'n Imperatief is nie 'n versteekte indikatief nie (Quist 1989:19). Die imperatief rus wel op die indikatief:

Werk julle eie heil uit met vrees en bewing, want dit is God wat in julle werk om te wil sowel as om te werk na sy welbehae (Fil. 2:12-13).

Omdat die mens ook subjek is van die heilstoe-eiening, maar nie op dieselfde manier as wat die Heilige Gees Subjek is nie, kom persoonlike faktore by wat in die toe-eiening van die heil 'n rol speel. By heilstoe-eiening kan die karakter-, persoonlikheids- en temperamentsverskille van 'n verbondskind nie gë̈gnoreer word nie. Die Gees "neemt als Subject van de toeëigening onze eigenaardigheden in Zijn hand. Deze blijven geen belemmering om het heil te ervaren" (Velema 1989:44). 
Oor hierdie laaste handeling, naamlik dat "die gelowige homself die heil toe-eien”, skryf Van't Spijker (1991:324), is die mees geestelike werksaamheid wat daar is. Dit dui op die verbondskinders in wie die Heilige Gees sy heilstoe-eienende werk doen. Hulle glo, hulle bekeer hulle, hulle leer amen sê en hulle aanvaar die heil, hulle leer om hulle skuld te bely, hulle leer om te hoop, hulle aanbid en verwag, hulle verheug hulle en hulle leef in toekomsverwagting. Met al die werkwoorde word die verbondskind se geloofsaktiwiteite beskryf aktiwiteite waarvan hulle die subjekte is (Velema 1989:44).

\section{CHRISTUS IS DIE SENTRUM VAN QUA EN QUAE}

As quae en qua teenoor mekaar gestel word, is Christus die sentrum van die quae én die qua. Christus is die inhoud van die objektiewe geloof en die inhoud van die subjektiewe uitlewing van die geloof.

- Die persoonlike aard van die quae word gereflekteer in die persoonlike aard van die qua.

- Die pro me-aard van die quae vind sy subjektiewe afdruk in die hart van die gelowige. Wie glo, glo nie net met die verstand (hoof) nie maar óók met die hart en die hand. Glo is nie net die verstandelike instemming met 'n aantal teoretiese waarhede nie, maar ook vertroue en dus alreeds eksistensieel (aanwesig) van aard. 'n Mens glo met jou ganse bestaan (Nel 2000:31).

Dit is noodsaaklik dat in hierdie opsig baie duidelik onderskei word om die gevaar van dwaling vroegtydig raak te sien.

- As kennis, geloofsinhoud (quae), en vertroue, geloofsdade (qua), van mekaar geskei word, word albei aan die gevaar van eksistensialistiese misverstaan blootgestel en dit kan lei tot 'n oppervlakkige mensgeworde leefstyl.

- Indien geloof primêr as vertroue verstaan word - in teenstelling met kennis - kry persoonlike geloof maklik 'n eie gewig. So 'n interpretasie is in stryd met die ware geloof, want geloof kry dan 'n kreatiewe funksie, wat dit nie het nie.

- Indien die quae nie die qua bepaal nie, maar die omgekeerde vind plaas, word God se genadebeloftes maklik Arminiaans as 'n algemene, ongeadresseerde aanbod verstaan. 


\section{DIE VERHOUDING TUSSEN OBJEKTIEWE HEIL EN SUBJEKTIEWE GELOOFSDAAD}

Binne die beskouing van vryheid en gebondenheid ontmoet die twee lyne van Goddelike vrymag en menslike verantwoordelikheid mekaar op 'n spanningslose wyse in die heilstoe-eiening. Dit leer die doopsformulier:

Omdat alle verbonde uit twee dele bestaan, daarom word ons ook weer deur die doop vermaan en verplig tot 'n nuwe gehoorsaamheid.

- Bogenoemde uitgangspunte leer God ons in sy verhouding met Noag. Die objektiewe heil is in die woorde: "Maar Noag het genade gevind in die oë van die Here" (Gen. 6:8). Die subjektiewe geloof is ingesluit in God se opdrag: "Maak vir jou 'n ark van goferhout" (Gen. 6:14). As Noag net vasgehou het aan die boodskap van genade en redding (quae) en self niks gedoen het nie (qua), sou hulle die sondvloed nie oorleef het nie. Die objektiewe heil word vir Noag en sy gesin 'n werklikheid toe hy deur subjektiewe geloof in gehoorsaamheid antwoord op God se belofte. So is sy geloof verwerklik.

- Die verhouding is ook duidelik in die gebeurtenis met die koperslang (Num. 21:4-10). Die objektiewe heil sit in die woorde:

Maak vir jou 'n beeld van 'n giftige slang en sit dit op 'n paal; dan sal elkeen wat gebyt is en daarna kyk, lewe (vs. 8).

Die subjektiewe geloof is ingesluit in God se opdrag om 'n beeld van 'n giftige slang te maak, op 'n paal te sit en daarna te kyk. As Moses net na God se verlossingswoord (quae) geluister het en nie die beeld van die slang gemaak en op die paal gesit het nie (qua) sou die volk aan die slangbyte gesterf het. As die volk, van hulle kant, net die verlossingswoord (quae) gehoor het en nie deur die geloof na die slang op die paal gekyk het nie (qua) sou hulle ook nie gered word nie. Die objektiewe heil (quae) word egter vir Moses en die volk 'n werklikheid toe hulle deur subjektiewe geloof (qua) gedoen het wat God van hulle gevra het. Hulle geloof word 'n aktiewe geloof in gehoorsame geloofsdade (geloofsverwerkliking).

In die Handelinge van die apostels is dit duidelik dat die leiding van die Heilige Gees nie buite die verantwoordelikheid van die gelowige om gaan nie (Hand. 20:22; 21:4). Versteeg (1976:27) skryf hieroor soos volg: 
Wanneer we tussen de leiding van de Geest en de overwegingen van de gelovige een tegenstelling maken, maken we een tegenstelling die het Nieuwe Testament niet kent.

Die gelowige is by die leiding van die Heilige Gees betrokke; hy verloor nie dan sy eie verantwoordelikheid nie.

\section{VERANTWOORDELIKHEID TOT HEILSTOE-EIENING EN DIE VERWERKLIKING VAN DIE GELOOF}

Die genade van God maak nie van verbondskinders passiewe, lydelike mense nie. Die verbond maak die mens aktief (Van der Vegt s.a.:35). 'n Verbondskind word die belofte in die verbond deelagtig deur geloof en bekering (Heidelbergse Kategismus Antwoord 60[k] en 84[a]; Polman s.a.:315; Bavinck 1967:211; Van der Vegt s.a.:34). Geloof en bekering

golden wel algemeen als noodzakelijke weg tot de zaligheid; maar deze stonden toch ten slotte in de vrijheid van den mensch. De zaligheid was wel objectief door Christus verworven, maar om haar deelachtig te worden, was de vrije medewerking des menschen van noode (Bavinck 1967:503).

In die verbondsverhouding roep God die verbondskind tot geloof en bekering (Mark. 1:15); tot 'n nuwe gehoorsaamheid. Met die verbondsbeloftes en verbondseise moet die verbondskind persoonlik werksaam word om te kom tot ware en volle belewing van die genadeverbond. Geloofsdade as antwoord op die heilsbelofte is heilstoe-eiening (verbondsinwilliging). Deur heilstoe-eiening word die paraklese van die Nuwe Testament deur die gelowige in die praktyk van die lewe toegepas. Dit wil voorkom asof dit juis dié sake is wat getoets moet word tydens belydeniskatkisasie, want genoemde sake impliseer heilstoeeiening, dit is heilsekerheid. Heilsekerheid vra dade wat by die bekering pas. Gedoopte kinders wat in die katkisasie onderrigleer ontvang, is dooplidmate wat die beloftes van God hét. Deur kategese moet die kind begelei word tot sekerheid, aanvaarding en toe-eiening van die verbondsbeloftes van die heil in Christus. Uit die Woord van God moet die werklikheid van die verbondsbeloftes vir die kinders geproklameer word. Die uitnodigende aanbod van genade word tot hulle gebring. Tydens die katkisasiejare gaan dit nie net uitsluitlik om die objektiewe heils- 
inhoud nie asof die taak van die verwerkliking van die geloof eers ná belydenisaflegging aan die orde kom nie. Tydens kategetiese onderrigleer word verbondskinders begelei om die genade deelagtig te word. Verbondskinders word immers deur die doop vermaan en verplig tot 'n nuwe gehoorsaamheid. Die quae moet saam met die qua tot die verbondskind gebring word. Via kategetiese onderrig word die volgende gedoen: Jy proklameer God se verbondsbeloftes aan die verbondskind. Jy bring aan hom die waarheid dat hy die merkteken van die verbond dra. Jy bring aan hom die rykdomme van God en ook die waarheid dat jy salig is as jy dit glo en omhels. As jy hierdie dinge verwerp, wag die ewige ondergang (voorbeelde is onder andere Kain, Esau, Saul, Judas en die ryk jongman).

Al hierdie dinge spreek uit die dankgebed by die doop van 'n verbondskindjie:

... sodat hy/sy Christelik en godvrugtig opgevoed mag word en in die Here Jesus Christus mag groei en toeneem, sodat hy u vaderlike goedheid en barmhartigheid wat $\mathrm{U}$ aan hom en ons almal bewys het, kan bely en in alle geregtigheid onder ons enigste Leraar, Koning en Hoëpriester, Jesus Christus, kan lewe en moedig teen die sonde, die duiwel en sy hele ryk kan stry en oorwin, om U en u Seun Jesus Christus en ook die Heilige Gees, die enigste ware God, ewig te loof en te prys.

God gebruik die amptelike kategese as middel om verbondskinders deur die werking van Gees en Woord tot geloof en bekering, tot heilstoeeiening te bring. Heilstoe-eiening is geesteswerk deur middel van die Gees en Woord (J.H. Velema 1947:116; Polman s.a.:315). Die belofte van die Gees (quae) gaan aan die gelowige aanvaarding van die verbond, die verbondsinwilliging of heilstoe-eiening (qua) vooraf, en bewerk dit (Jes. 59:21; Jer. 31:31-33) (Polman s.a.:315; Bavinck 1967:211). Dit is die Gees, wat "ons de beloften doet aanvaarden uit een herboren hart" (Polman s.a.:303). Die beloof van God roep om geloof. Die bely moet kom tot belewe.

Iewers gaan hierdie beklemtoning in die kategese dalk verlore. Een rede mag wees dat die kategese net op kognitiewe vlak geskied. Sodanige onderrig beteken dat die bediening van God se Woord nie verder kom as die geloofsinhoud (quae) nie. Dan beskou verbondskinders die leerinhoud van die kategese op dieselfde manier as die leerinhoude van hulle skoolvakke: lesse word in die klaskamer aangebied en die 
kinders neem aantekeninge af of volg in die handboek. Met die inhoud as sodanig hoef niks verder gemaak word nie, tot en met die eerste toets geskryf word of die eksamen aanbreek. As die eksamen verby is, is die belangrikheid van die leerinhoud ook verby tot die volgende eksamen. Volgende jaar word met nuwe leerinhoude begin en dus is die vorige jaar se leerinhoude vir goed vergete. Hierdie gesindheid in die kategese sal dringend aandag moet kry, want daar is 'n ooreenkoms en verskil tussen kategese en skoolonderrig.

Kategese en skoolonderrig het albei te doen met onderrigleer. Skoolonderrig sluit ook kultuur as leerinhoud in. Die leeruitkoms van skoolonderrigleer en kategese verskil egter wesenlik. Die leeruitkoms van die kategese is gerig op 'n persoonlike geloofsverhouding met God. Skoolonderrigleer is suiwer gerig op die verkry van kennis, houdings en vaardighede binne 'n bepaalde kultuursituasie. Net soos by skoolonderrigleer in didaktiese sin, het kategese wel met die onderrigleer van kennis te doen, maar dit is 'n eiesoortige onderrigleer wat unieke kennis tuisbring, kennis wat los van en bo enige menslike kultuur staan (Spoelstra 1990:22). Kategese het te doen met geopenbaarde kennis/waarhede (veritates revelatae). Kategese is onderrigleer uit die Woord van God, as Godsopenbaring. Die doel met hierdie tipe onderrig is dat 'n verbondskind verantwoordelik, selfstandig en persoonlik sy innige verbondenheid aan God deur geloof sal bely en verder met sy leer en lewe sal bewaarheid (Spoelstra 1990:23). ${ }^{5}$ Die leeruitkoms van die kategese is om die kind se geloof te laat toeneem in kennis, begrip, insig, onderskeiding, omhelsing, belydenis, getuienis en blydskap van die volle inhoud van die Woord van God (Van der Walt 1992:11).

5 Deur kategetiese onderrigleer en skoolonderrigleer gelyk te stel, het Larry Richards gefouteer as hy skryf oor A theology of Christian education (1975) waarin hy "Christian Education” dan beskou as sinoniem met kategese (1975:77). Hy maak die verwarring groter deur te verklaar "Christian Education" is "the concept of teaching as shaped by our culture" (1980:127). Richards (1980:127) haal Meyer Fortes instemmend aan as hy skryf dat opvoeding in die wydste betekenis van die woord "the process by which the cultural heritage is transmitted from generation to generation" is en dat die wesenlike taak van die opvoedkunde "the moulding of individuals to the social norm" is. Kategese en skoolonderrigleer is nie dieselfde nie. Dit is die duidelikste sigbaar as gelet word op die leeruitkoms en leerinhoude van elkeen. 


\section{MENSLIKE VERANTWOORDELIKHEID EN DIE VERWERKLIKING VAN DIE GELOOF}

Wat goddelike genade en menslike verantwoordelikheid betref, skryf Berkhof (1973:494) dat dit onder andere gaan om die verhouding tussen heiliging en heil. Hierdie beklemtoning bring 'n paar ernstige vrae na vore. Kan 'n mens van die standpunt uitgaan dat hy geheel en alleen deur die vryspraak tot kind van God aangeneem is? Is die aanneming dan nie minstens mede-afhanklik van die wyse waarop die mens hom inspan om die heil toe te eien nie? Kan die gelowige sê dat hy alleen deur genade gered word? Moet die mens dan nie in 'n mate met die genade meewerk nie? Die begrip meewerk is te vlak in betekenis om die verhouding uit te druk. Deur sy werke voeg die mens niks by tot die voldonge genade waarop hy hom in die geloof verlaat nie:

Wij werken niet met de genade mee, maar door het geloof wordt de genade operationeel; haar aanwezigheid blijkt door wat ze uitwerkt (Berkhof 1973:494).

Hierdie uitspraak beteken dat die verlossing in sy geheel ten volle deur God afgehandel is alvorens die mens opgeroep word tot heilstoeeiening. Deur die geloof word die uitverkorene in Christus ingelyf en neem al sy weldade aan (HK:20). "Inlyf" staan teenoor "weldade aanneem".

\section{GENADE IS WERKSAAM IN GELOOFS- VERWERKLIKING}

Genade is op drie vlakke toepaslik vir geloofsverwerkliking vir die verbondskind:

- $\quad$ in die uitverkiesende genade waardeur God die Vader die heil beskik vir elkeen op wie Hy in die uitverkiesing besluit het (Ef. 1:4-6);

- in die versoenende genade waardeur God die Seun die heil verwerf vir elkeen wat deur die Vader uitverkies is (Ef. 1:7-12);

- in die verseëlende genade waardeur God die Heilige Gees die heil aan sy uitverkore kinders bedien (Ef. 1:13-14).

As die genade, deur die geloof, werksaam is, is dit sigbaar in lewensdade wat by die genade en die geloof pas. In hierdie opsig moet die volgende onderskei word: die mens werk nie met die genade nie, maar 
in die genade deur die geloof, want so is die gelowige by Christus ingelyf, en word die genade sigbaar in die mens se woorde en dade (Jak. 1:19-27; 2:14-26). Slegs diegene wat

door het geloof de krampachtigheid tot "werken" en "heiliging" verliest, kan iets uitwerken dat aan zijn leven met God en de naaste vruchtbaarheid en voortgang verleent (Berkhof 1973:495).

\section{PRAKTIESE BETEKENIS VIR DIE VERWERKLIKING VAN DIE GELOOF IN DIE KERKLIKE KATEGESE}

Die verhouding tussen fides quae en fides qua het besliste konsekwensies — nie net vir die onderrig tot geloofsverwerkliking in die kategese nie, maar veral ook in die ondersoek van verbondskinders wat aansoek doen om belydenis van geloof af te lê. In hierdie opsig moet in gedagte gehou word dat kinders op verskillende leeftydfases tot geloofsrypheid kan kom. In die kerklike praktyk word nog steeds te sterk gefokus op 'n bepaalde leeftyd vir almal (gewoonlik vind belydenisaflegging in die laaste skooljaar plaas). Kerkrade en ondersoekkommissies sal daarom in 'n sterker mate moet individualiseer en meer soepelheid aan die dag moet lê wanneer bepaal word wanneer kinders belydenis van geloof (behoort) af te lê. Geloofsekerheid en die bely van jou geloof kan nie geforseer word nie en is ook nie iets wat "outomaties" op 'n sekere tydstip in jou lewe behoort plaas te vind nie.

Verbondskinders kan egter met groot vrymoedigheid bely dat hulle die geloofswaarhede aanvaar en as geloofsryp geag word as hulle self laat blyk dat hulle oortuig is van hul voorneme om openbare belydenis af te lê. Op grond van verbondskinders se aanvaarding van geloofswaarhede kan hulle toegelaat word om belydenis te doen, maar op hierdie wyse kan dit ook gebeur dat die geloofsinhoud losgemaak word van geloofsdade. In sulke gevalle word in die praktyk geoordeel op grond van die objektiewe geloofsinhoud (quae), die geloofskennis waarvan die katkisant dalk baie goed rekenskap kan gee, terwyl daar nie altyd gelet word op die subjektiewe geloofsdade nie. Daar is dus 'n moontlikheid dat die qua los staan van die quae. Dan word die voorbeeldige lewenswyse van 'n katkisant verkeerdelik gesien as geloofswerke, terwyl die katkisant dalk bloot 'n oppervlakkige, 'n algemeen geldende, hu- 
manistiese en eksistensiële beginselraamwerk gebruik om 'n "vroom en goeie" lewe te vertoon. Dit kan dus beteken dat die lewe van die kind nie gewortel is in God en sy Woord nie. Die uitkoms van die kategese moet dus nie vassteek by geloofsekerheid (certitudo fidei) nie, maar moet verder uitkring na die heilsekerheid (certitudo salutis) wat in lewensdade sigbaar word.

Daarom is dit noodsaaklik dat die besondere uitstaande eienskappe wat die verbondskind in elke lewensfase beleef, in ag geneem moet word in die praktyk van die kategese. Die volgende gedagtes kan as riglyn dien vir die praktyk van die kategese aan die tiener met die oog op die realisering van die geloof:

- Die liefde en genade van God moet in die kategetiese leerinhoude sterk beklemtoon word, omdat verbondskinders normaalweg 'n diep hunkering en verlange daarna het.

- Die verbindingslyne tussen Godsopenbaring, belydenis van die kerk, kerkgeskiedenis en die praktiese lewe moet aandag en beklemtoning ontvang.

- Die leerinhoude van die kategese moet vir die kind "lewe" en nie iets bly uit die verre verlede nie. Die aanbieding van elke les deur die kategete kan egter 'n probleem wees omdat kategete in die onderrigleer moontlik sal voortgaan om lesse aan te bied soos dit in die verlede die gebruik was, naamlik met die oorbeklemtoning van die quae terwyl die qua óf geïgnoreer word óf verwaarloos word. So 'n onderrigwyse het veral ten opsigte van tieners 'n negatiewe uitwerking omdat 'n verbondskind homself nie kan "ontdek" en ook nie sy eie lewe kan orden in die lig van die Skrif nie. Die leerinhoude moet sodanig aangebied word dat dit deel kan word van sy praktiese lewe.

- Norme en waardes moet beklemtoon word.

- Die regte verhouding tussen wet en evangelie moet aandag ontvang.

- Die uitnodigende aard van die godsdiens moet beklemtoon word, sonder om die regte verhouding tussen genade en oordeel, verkiesing en verantwoordelikheid te vermy.

- Kategetiese leerinhoude moet rustig en sistematies behandel word en argumente moet oortuigend en Bybelgefundeerd wees. 
- Herhaling van die hooflyne van die leerinhoude is noodsaaklik, sodat insig in die Bybel verbreed kan word.

\section{BIBLIOGRAFIE}

\section{ANDERSON N T}

1993. Each new day with Neil T. Anderson. Eugene, Oregon: Monarch Books.

\section{BAVINCK H}

1967. Gereformeerde Dogmatiek. Derde deel. Kampen: Kok.

\section{BERKHOF H}

1973. Christelijk geloof. Een inleiding tot de geloofsleer. Nijkerk: Callenbach.

1990. Christian faith. An introduction to the study of the faith. Revised. Grand Rapids:

Eerdmans.

\section{BYBEL}

1933. Die Bybel: dit is die ganse Heilige Skrif wat al die kanonieke boeke van die Ou en Nuwe Testament bevat. Kaapstad: Britse en Buitelandse Bybelgenootskap.

1983. Die Bybel: nuwe vertaling. Kaapstad: Bybelgenootskap van Suid-Afrika.

\section{CALVYN J}

1984. Institusie van die Christelike godsdiens. Vertaal deur H.W. Simpson met medewerking van L.F. Schulze en C.C.C. Brink. Potchefstroom: Calvyn Jubileum Boekefonds. 4 dele.

\section{DEIST F}

1984. A concise dictionary of theological and related terms. Pretoria: Van Schaik.

FORMULIER VIR DIE AFLEGGING VAN BELYDENIS VAN DIE GELOOF 2001. In: Psalmboek. Wellington: N.G. Kerk-Uitgewers.

FORMULIER VIR DIE BEDIENING VAN DIE HEILIGE DOOP AAN KINDERS 2001. In: Psalmboek. Wellington: N.G. Kerk-Uitgewers.

FORMULIER VIR DIE VIERING VAN DIE HEILIGE NAGMAAL 2001. In: Psalmboek. Wellington: N.G. Kerk-Uitgewers.

\section{Gereformeerde Kerke IN SuId-Afrika (GKSA)} 1958. Handelinge van die $33^{e}$ sinodale vergadering. Potchefstroom: Deputate vir die uitgee van die handelinge van die sinode van 1958. 
1961. Handelinge van die $34^{e}$ sinodale vergadering. Potchefstroom: Deputate vir die uitgee van die handelinge van die sinode van 1961.

1964. Handelinge van die $35^{e}$ sinodale vergadering. Potchefstroom: Deputate vir die uitgee van die handelinge van die sinode van 1964.

1988. Handelinge van die $43^{e}$ sinodale vergadering. Potchefstroom: Deputate vir die uitgee van die handelinge van die sinode van 1988.

1991. Handelinge van die $44^{e}$ sinodale vergadering. Potchefstroom: Deputate vir die uitgee van die handelinge van die sinode van 1991.

\section{GKSA KyK: Gereformeerde Kerke IN SuId-Afrika}

\section{GRAAFLAND C}

1961. De zekerheid van het geloof. Een onderzoek naar de geloofsheschouwing van enige vertegenwoordigers van Reformatie en Nadere Reformatie. Wageningen: Veenman \& Zonen.

\section{HEYNS J A}

1978. Dogmatiek. Pretoria: N.G. Kerkboekhandel.

\section{JONKER W D}

1981. Die Gees van Christus. Wegwysers in die dogmatiek. Pretoria: N.G. Kerkboekhandel.

\section{NEL C}

2000. Die verhouding tussen die objektiewe heil en die subjektiewe geloof in die heilstoeëiening by P.F. Theron. Ongepubliseerde M.Th.-skripsie. Bloemfontein: Universiteit van die Vrystaat.

\section{Polman A D R}

s.a. Woord en belijdenis. Deel 1. Franeker:Wever

\section{PRINS J M G}

2000. Geloofsoortuigings, -ervarings en -gedrag van kerklik betrokke tieners — verslag van 'n empiriese ondersoek. NGTT 41(1 \& 2):15-27.

\section{QUIST W J}

1989. De toeëigening des heils in de brieven van Paulus. In: W.H. Velema (red.), Delen in het heil (Kampen: Kok), pp. 87-120.

\section{RICHARDS L O}

1970. Creative Bible teaching. Chicago: Moody.

1975. A theology of Christian education. Grand Rapids: Zondervan.

\section{Richards L O \& HOELDTKE C}

1980. A theology of church leadership. Grand Rapids: Zondervan.

\section{Richards L O \& BREDFELDT G J}

1998. Creative Bible teaching. Revised and expanded. Chicago: Moody.

\section{SPOELSTRA B}

1990. Gereformeerde Kategetiek en kategese. Afdeling 2. Historiese Kategetiek. Klasdiktaat. Potchefstroom: PU vir CHO. 
STRAUSS S A

1989. Verbond en bekering. Acta Theologica 1989(1):79-88.

\section{Theron P F}

1985. Verbond, geloofsekerheid en belydenisaflegging. NGTT 26(3):299-310.

\section{VAN DER VEGT W H}

s.a. Het verbond der genade bij Calvyn. Aalten: De Graafschap.

VAN DER WALT J J

1992. Toegerus om te onderrig. Potchefstroom: EFJS.

\section{VAN 'T SPIJKER W}

1991. Toeëigening van het heil (3). De Wekker 100(37/38):323-324.

\section{VAN GENDEREN J}

1977. De continuiteit van geloof en kerk. Kampen: Kok.

\section{VELEMA J H}

1947. Wat is Christelijk Gereformeerd? Amsterdam: Duwaer.

\section{VELEMA W H}

1989. De toeëigening van het heil in de prediking. In: W.H. Velema (red.), Delen in het beil (Kampen: Kok), pp. 30-35.

1990. Nieuw zicht op gereformeerde spiritualiteit. Kampen: Kok.

\section{VERBOOM W}

1989. De toeëigening van het heil in het pastoraat. In: W.H. Velema (red.), Delen in het beil (Kampen: Kok), pp. 170-189.

\section{VERSTEEG J P}

1976. De Geest en de gelovige. De verhouding van de werk van de Geest en het werk van de gelowige volgens het Nieuwe Testament. Kampen: Kok. Apeldoornse Studies.

\section{WENTSEL B}

1995. De Heilige Geest, de kerk en de laatste dingen. Die persoon en het werk van de Heilige Geest. Dogmatiek. Deel 4. Kampen: Kok.

\section{WILSON N S}

2000. The handbook of Bible application. Wheaton, Ill: Tyndale House. 
Trefwoorde

Kategese: aard en proses van

Belydenisaflegging

Verwerkliking van geloof

Fides quae creditor

(Objektiewe heilstoe-eiening)

Fides qua creditor

(Subjektiewe heilstoe-eiening)
Keywords

Catechesis: nature and process of Confirmation of faith

Realisation of faith

Fides quae creditor

(Objective receiving of salvation)

Fides qua creditor

(Subjective receiving of salvation) 